\title{
H. Gregg Lewis Memorial Comments
}

\section{Citation}

Ashenfelter, Orley, Sherwin Rosen, Richard B. Freeman, and Marjorie B. McElroy. 1994. H. Gregg Lewis memorial comments. Journal of Labor Economics 12(1): 138-154.

\section{Published Version}

doi:10.1086/298347

\section{Permanent link}

http://nrs.harvard.edu/urn-3:HUL.InstRepos:4631950

\section{Terms of Use}

This article was downloaded from Harvard University's DASH repository, and is made available under the terms and conditions applicable to Other Posted Material, as set forth at http:// nrs.harvard.edu/urn-3:HUL.InstRepos:dash.current.terms-of-use\#LAA

\section{Share Your Story}

The Harvard community has made this article openly available.

Please share how this access benefits you. Submit a story.

\section{Accessibility}




\title{
H. Gregg Lewis Memorial Comments
}

\author{
Orley Ashenfelter, Editor
}

\section{Introduction}

H. Gregg Lewis, perhaps the father of modern labor economics, died in January of 1992. The comments that follow were written for presentation at a special memorial session, held at the American Economic Association Meetings in Anaheim, California, in January of 1993.

I first learned about Gregg Lewis from his incredibly painstaking academic research. Gregg's research was careful, detailed, and, above all, "credible." His research results were not influenced by politics but instead were deeply empirical. The fact that some preconceived "theory" might not be proved did not bother Gregg.

I believe that the widespread emulation of this research style represents Gregg's lasting impact on economists. Younger economists may take Gregg's posture for granted and even expect significant rewards in the academic marketplace when they focus on the care and credibility of their research. Without Gregg I think things would be different.

For some of us there are also personal, as opposed to professional, reminders of Gregg's work. I first met Gregg and Julia Lewis in 1974 when they spent the year visiting Princeton. It was then that I learned of the Lewis passion for art and of Gregg's precisely constructed mobiles. (Obtaining one of these creations required some serious effort; I obtained two!) I still find it remarkable that a man whose professional work required such attention to detail would turn to so meticulous an enterprise for relaxation.

It is always worthwhile taking a few moments to remember how we got where we are. That is the purpose of the comments that follow.

Orley Ashenfelter June 1993

[Journal of Labor Economics, 1994, vol. 12, no. 1]

(C) 1994 by The University of Chicago. All rights reserved.

0734-306X/94/1201-0007\$01.50 


\section{H. Gregg Lewis and Modern Labor Economics}

We tend to measure scholars by their influence in a profession. Gregg Lewis, as one of the founders of modern labor economics, ranks high on such a scale, but his memory is not particularly emblazoned in a thick paper trail. His publications are few in number and citations to them are relatively small. Lewis's influence largely was achieved in a more personal and unusual way, as one of the outstanding teachers of applied economics. Empirical confirmation of this claim requires data of a rather different kind than what is found on curriculum vitae and the like. It requires surveying the many economists in the profession today who were greatly influenced by him. What follows is the testimony of one such respondent.

Certainly Gregg was a considerable scholar in his own right. His comprehensive research on how trade unions affected wages revitalized that subject. It provoked research by others that brought new evidence to bear on the question and helped forge strong links between econometrics and labor economics. But, on the whole, his published research was known mainly to specialists. Also, his reputation as a classroom teacher grew over the years. He won a coveted undergraduate teaching award at the University of Chicago in 1972, and his detailed set of graduate course notes on production theory got wide underground circulation in the profession. Yet his real forte wasn't in the classroom. It was in one-on-one teaching in his office, discussing thesis problems and progress, and training young economists how to do research. He had no peer in those endeavors. He was extraordinarily unselfish and generous to students in giving away his ideas, time, and criticism. It helped shape the content and professional style of the field.

Gregg was deeply involved with a remarkable number of Ph.D. dissertation students over the years. Between 1950 and 1976 he served in a significant advisory capacity on almost 90 completed thesis committees at the University of Chicago, and on many after that at Duke University, where he moved in 1976. None of this work is joint or collaborative in the official sense. A large number of these dissertations meet the highest intellectual standards, and many have been influential in economics. The topics range all over the map. Gregg was quick to see the virtues of what were considered to be odd problems in labor economics before others did and to encourage and work closely with Ph.D. students on them. What was off the beaten path back then has become mainstream today. These studies helped put labor economics into the vanguard of empirical economic research. He was a pioneer in promoting empirical research with strong microeconomic foundations and in expanding the range of substantive problems that were amenable to economic analysis. This may be his most important legacy to economics. 
These kinds of skills are exceedingly rare in academic life and celebrated mostly in lore-Lewis on one end of the $\log$ and a graduate student on the other end is not a bad description of how he worked. Though research is essentially a cooperative enterprise within a professional society, the assignment of individual credit and attribution are too important in academic circles for this style to attract many practitioners. Working as Gregg did has enormous common property elements. These are greatly admired by graduate students (the overgrazers, as it were) and not so highly valued by peers and administrators because they are difficult to measure and to assess. It took far too long for Gregg to gain the external recognition he deserved because his name seldom appears on most of his life's work. Instead, it is in acknowledgments and the indebtedness, impossible to repay, of the countless numbers whom he taught to be economists.

When Lewis entered the field in the early 1940s, he hardly was recognized as a labor economist, and his work remained outside the main thrusts of the field until the 1960s. Institutional approaches dominated labor economics prior to the 1930s, and the mass unemployment of the Great Depression and the rise of trade unionism made a thoroughgoing economic approach to labor unattractive to most economists. Rational models were ridiculed, marginal productivity and the theory of the firm were considered irrelevant by labor economists, and wage determination was thought to be largely immune from competitive forces. Labor markets were "balkanized," and demand (and supply) curves had to be drawn with "the broad side of the chalk." Industrial relations had a stranglehold on the field, and few gains from trade were perceived from bringing much economics into it.

Time probably has proven those perceptions to have been correct, but unduly narrow. Gregg and others hardly solved all the problems that occupied labor economists in those days. Some were solved, to be sure, but many others still have not yielded much to economic ways of thinking. These largely were finessed and cordoned off. What Gregg helped accomplish was to shift the focus of the field to entirely new problems that could be sharply illuminated by economic models combined with sophisticated empirical work on increasingly high-quality data. His students wrote on such topics as the effects of unions on relative wages, labor market discrimination, slavery, human capital and the effects of training on wages, earnings inequality and occupational wage differentials, labor demand and elasticities of substitution, job safety, unemployment and employment variability, labor supply of married women, the value of time, fertility choices, and many more, long before the general research community picked up on them.

The labor courses and prelim didn't attract many graduate students at the University of Chicago even as late as my generation of the early 1960s. The appeal of the field to entrants in those days was its prospects for 
applying economics to substantive problems. Reading the literature to prepare for the labor prelim didn't particularly advance those interests because the field was dominated by institutional approaches. As a resource in both suggesting problems and helping to develop solutions to them, Lewis was much more important than most things one might read. Many of us who ended up working in the labor field at Chicago stumbled into it after searching for a thesis topic and for guidance from a generous and sympathetic thesis adviser. Gregg's reputation on both scores was well known to graduate students in the Economics Department, though broader recognition of his remarkable talents only came much later. What's more, he took on virtually all comers, from the best of students to the worst. Even with the weakest students, who Gregg often actively sought out, something interesting invariably materialized.

Gregg's professional life is inexorably linked to the University of Chicago, where he was undergraduate, graduate student, and faculty member for much of his adult life. He began studying there in the 1930s, when the department had an extraordinary faculty and what proved to be an extraordinary group of graduate students. Allen Wallis, one of the latter, has said that two undergraduates, Gregg Lewis and Paul Samuelson, especially impressed his circle of graduate students at the time. Gregg was strongly influenced by Henry Simons, from whom he learned price theory, and by Henry Schultz, from whom he obtained intense empirical interests. As a young man, he had outstanding prospects. He was a very good theorist, with mathematical and analytical skills that were far ahead of the profession in some ways. For example, he did some early work on duality theory. He was also an extremely capable statistician. In fact, he was first hired by the Department of Economics to replace Schultz in teaching statistics. Gregg was a stickler for detail, but techniques per se did not especially concern him. Mainly he was interested in analyzing empirical questions from a thoroughly economic perspective, and it was this empirical-theoretical combination that reoriented the field.

Gregg spent enormous amounts of time talking with students and thinking about their research. My own meetings with him were frequent, lengthy, and intense. On the whole, direct discussions were fairly freewheeling and friendly, though a clear teacher-student relationship always was maintained. However, some students had much more vigorous disagreements with him, including ultimatums and shouting matches on occasion.

More formal, written criticism was a different story. Gregg was a stern and unrelenting critic and invariably disagreed with almost every student on when a thesis was finished. He was in much less of a rush to declare a project completed than were students. One always had to take the time to nail down the loose ends and get it right! A war of attrition resulted, in which students usually won ultimately, though a few self-destructed. I well recall the lengthy and detailed comments he wrote on the drafts I 
sent him after leaving Chicago for my first job. His letters, written in a beautiful longhand, didn't mince words nor spare feelings. They followed a blunt style and stuck strictly to business-what was wrong with the previous draft. Some of them arrived in huge envelopes and seemed to go on forever, they took days to read and invariably requested more work. To this day I still have an occasional nightmare of receiving another letter from Gregg and submitting another draft of my thesis.

Gregg's criticism and insistence on perfection were applied with the most complete abandon on himself. He was a tightly wound person who held onto his own work too long and honed it excessively. He hardly ever deemed his own work good enough to expose to public scrutiny. The first unionism book is the most important work on a subject of central importance to the field, though few have actually read it. The book is too difficult. He lived with the material privately for so long that what became perfectly obvious to him was impenetrable for others. The notation is obscure and a high entry cost for readers, and the book takes far too much for granted. Even this had spillovers: It allowed some of us to make a good living expositing his methods and making them more accessible for a wider audience through secondary sources.

Other work scarcely saw the light of day. In the early 1960s Gregg had some advanced ideas about production function estimation that anticipated subsequent work on "flexible functional forms." I know he had worked out many of the details because he shared some of them with me, but if a manuscript ever was written, it was circulated to remarkably few. Publication of this material would have helped stimulate earlier development of those important ideas. A few years later Gregg and I had long and heated discussions about how wages and working hours were determined when the hours schedules of workers had to be coordinated. The solution required a new and sophisticated equalizing difference model that materially advanced the economics of hours of work. Somehow a manuscript never materialized. Many years later I discovered that he had in fact written an excellent conceptual paper that spelled out many details and published it in Spanish, in a Chilean journal that is virtually unread. The piece probably got wider circulation from duplicates of an English language version I later sent to friends. A reworked and independently discovered version of those ideas was published only a few years ago in a major journal under somebody else's name. It is hard to fathom why Gregg buried this work as he did.

A few other examples come to mind. One is a valuable early note on selectivity and labor supply that was reluctantly published after friends pressed hard on him to let the world in on what he knew. Another unpublished paper was one of the first to make the distinction between the extensive (participation) and intensive (hours of work) margins in labor supply behavior. The point was made in print, though not quite so well, 
by someone else. How many unpublished and virtually uncirculated notes and papers did Gregg produce in his life that have been lost to the profession?

I have never encountered an economist so talented as Gregg who had more modesty and less ego. His skepticism and apparent lack of confidence in his own work illustrate the difficulty of making unbiased assessments about one's self. Lewis may have been a leading example of Alfred Marshall's claim that people are apt to underrate themselves. Perhaps his career would have developed quite differently had he moved away from Chicago after completing his thesis and gained independence from the strong memories and expectations of his own teachers and some colleagues. Yet, I doubt if his work would have been as productive or of greater originality. Gregg adapted his skills and energies to working with graduate students and making their work far more important than it would have been without his guidance. The quality, volume, originality, and extraordinary variety of research in which he was engaged in this way had a much greater effect on his profession than the most ambitious of economists can imagine. His memory is important to all of us.

Sherwin Rosen University of Chicago

\section{H. G. Lewis and the Study of Union Wage Effects}

In the 1970s-early 1980s many labor economists going about their normal business-pondering why wages went up or down, why people worked or were jobless, hoping the latest econometric trickery would solve the problems of nonexperimental data, grooving on how the Invisible Hand made the labor market a thing of beauty, or how market segmentation impaired the Hand-received a letter or phone call from H. Gregg Lewis: "What exactly did you do to get your recent estimated union wage effects? Send me your computer printouts, files, information on sample restrictions, precise controls, definition of variables, etc."

The recipient of a Lewis communication would have two reactions.

First was pleasure. Their work had not gone unnoticed. At least one person in the scholarly universe had read their study and looked at their numbers. And that person was Gregg Lewis. Why, that meant the study was a contribution to knowledge. It might make it as a reference in Lewis's encyclopedic review of union wage studies. Wow!

The second was trepidation. Did Lewis's message mean he'd found a mistake? Should the recipient have structured the study differently? Analyzed different data? Controlled for more, or fewer, things? Or maybe become a bassoonist or professional wrestler instead of an economist? Thesis 
advisors, journal referees, mothers, fathers, and significant others hadn't noticed any blatant blunders, but Lewis ... a different kettle of fish entirely. Oh Millie!

This vignette shows one way $\mathrm{H}$. Gregg Lewis influenced cohorts of labor economists through creative syntheses of disparate studies of union wage effects. All of us who studied unions were part of an informal Lewis team searching for the truth about the most readily measurable trade union effect, with H. Gregg looking over our shoulders.

I refer to Lewis's work as "creative synthesis" rather than summary or review, for as any reader of his two books knows, his encyclopedic analysis went far beyond literature reviews or mechanical calculation of metastatistics. Lewis studied research output with the meticulousness of the ideal reader. If your estimate diverged from what he expected, he didn't dismiss it or attribute it to sampling variance or to a misprint. He checked what you did. And more often than not found some error.

By analyzing statistical studies with Kuznetsian care, Lewis influenced the way a generation of labor economists did empirical work. He was a conscience against the quick and dirty and shoddy ... even if that meant journal publication fast.

But there was more to Lewis than Master Synthesist of empirical findings. He had a theoretical power that surpassed that of many professed theorists. Reread his books on union wage effects or any of his articles and you see a subtle theorist's mind at work. In the books Lewis developed the basic analytic framework for interpeting union wage studies, stressing what we could or could not infer from the most careful data analysis. Reread, or read if you haven't, Lewis's lecture notes on labor demand (University of Chicago, 1970-71) and you will find the same theoretical perspective. Lewis's theory had a power beyond that of many highly mathematical types because his theory was grounded in economic, not mathematical, fine points and was directed at real issues that data can ultimately answer.

My brief review of Lewis's contribution to our profession will be personal and prejudiced. I cannot do otherwise. I took Lewis's courses at Chicago, lived in his house during the quarter he was away, absorbed his lecture notes on labor demand in my teaching, hosted him the summer he and Judy visited the National Bureau of Economic Research in Cambridge, dedicated a collection of papers to him (and some others who helped form my thinking about economics). At the same time, I will be critical, as I am sure Gregg would want me to be, for like the rest of us, he was not the perfect economist or social scientist, but a mixture of strengths and weaknesses.

The achievements that stand out most are the two books on union wage differentials: Unionism and Relative Wages in the United States: An Empirical Inquiry (Chicago: University of Chicago, 1963) and Union Relative Wage Effects: A Survey (Chicago: University of Chicago, 1986). If one were to 
caricature, in the manner of student skits, the Chicago economists of Lewis' era, there would be Al Harberger-Triangle Man; Milton FriedmanMVPQ; Harry Johnson-Trade Diagram Man; Bob Fogel-Mr. Slavery. And Gregg Lewis-Union Diff Man.

The books differ in important ways, and the differences show some of Lewis's scientific strength. The first book, written before micro data were available to estimate union wage differentials, is based largely on comparisons of unionization rates and wages across industries and regions. Most, though not all, of the studies are from Chicago theses, and the book contains substantial primary evidence that Lewis generated himself (with Judy's help, I would guess). The second book, written after the micro-data revolution, at the height of structural modeling in labor economics, was based on a wide set of studies that used micro data on individual workers, including some panel studies. Most of these studies were not Chicago theses. Almost to the publication date, Lewis was adding studies to those in his synthesis.

In the second book Lewis assessed differences in methodologies for studying union wage effects. He first addressed the value of estimates of union effects obtained by comparing wages across aggregations that differ in unionization. Although such comparisons were the meat of Unionism and Relative Wages in the United States, Lewis was harsh on them: "Are these 'relative wage effect' estimates also wage gap estimates? ... I prove that they are not. Instead they are exactly or approximately estimates of the sum of the union/nonunion wage gap and a separate extent of unionism effect. I also show that estimates of this extent of unionism effect are very sensitive to the choice of the particular extent of unionism variable used and to the specification of the set of wage-explanatory control variables ... As a consequence ... the extent of unionisation effect cannot be decomposed with useful precision into its two components" (p. 4).

In my view and that of many other scholars who continue to cite the summary conclusions Lewis reached in the book-10\%-15\% union premium in the 1950s and 1960s-this is too harsh a verdict. Still, what is impressive is Lewis's willingness to downplay work and methods he had pioneered in the face of scientific progress. May we all be as open-minded when new data, technology, whatever, surpasses our past efforts.

I relate the second issue with a personal diversion. At a seminar long before Lewis finished the second book, I got into a row with an econometrician about the newest structural model estimates of union effects. The new estimates diverged from Lewis's. Therefore, the econometrician declared blithely, Lewis was obsolete, done in by fancy technique. The idea that the road to truth lay in maximum likelihood estimates of structural models rather than in Lewis's careful investigation of union wage differentials grated, as you might expect. It spurred me to review the existing structural estimates of union wage effects. My review convinced me that 
these estimates were nonrobust and thus not particularly useful: some exceeded standard estimates by nonsensical levels, some produced unbelievably low or negative union effects, and slight differences in models produced strikingly different effects (R. Freedman and J. Medoff, "The Impact of Collective Bargaining: Illusion or Reality?" in U.S. Industrial Relations, 1950-80: A Critical Assessment, ed. Jack Steiber, Robert McKersie, and D. Quinn Mills [Madison, WI: Industrial Relations Research Association, 1981]). Far from making Lewis's analyses obsolete, these studies showed that it required careful detailed scholarship of the Lewis mode, not econometric shenanigans, to find the truth and lay out what we could or could not deduce from the evidence.

The tone of the times was that many disagreed with this assessment, but that did not bother me. What mattered was what Lewis, the arbitrar of these issues in my mind, thought. He would give an utterly honest assessment. If he believed structural modeling worked, he'd dismiss the existing literature as readily as he had the older cross-region or industry analyses. And my faith in Gregg's judgment was such that if he so decided, I'd feel impelled to rethink my reading of the evidence.

Shades of the E. F. Hutton advertisement, when Gregg Lewis spoke on an issue, you listened. One of Lewis's virtues was that he did not speak, much less write, before he thought matters over in great depth. Thus, I read Lewis's assessment of structural estimates in the preprint to his second book with great interest. He was harsh on complicated econometric structural models: "The SE (simultaneous equations) estimates are very much more dispersed than the OLS estimates. They are not systematically smaller than the OLS figures or consistently larger. Furthermore, the SE figures display considerable sensitivity to the set of variables included in the wage and union status equations, the fitting techniques used, the assumptions made about the error terms in the equations, and the set of data to which the equations were fitted. The dispersion around zero of the differences between the OLS wage gap estimates and their matching and supposedly unbiased SE counterparts is so large that not even the sign of the omittedvariable or selectivity bias in the OLS figures is clear" (Union Relative Wage Effects, pp. 4-5).

That settled the issue.

There was another area in which I awaited nervously Lewis's assessment of the evidence. An open question about union effects was whether unions increased or reduced inequality. In his first book, Lewis estimated the extent to which union differentials increased inequality between otherwise similar workers. He recognized that if unions reduced inequality among union members through standard wage rates, they might on net lower inequality but expressed doubt that the standardization effect was that large. In a set of papers, I had estimated the differences between the dispersion of wages among union and nonunion workers and concluded that 
the reduction in dispersion among unionists, together with the unioninduced reduction in blue-collar/white-collar differentials, dominated the inequality calculus. On net, unions seemed to reduce inequality. But not until I read Gregg's assessment of the issue did I feel comfortable that this was more or less the right conclusion. After going over the methodology of the calculations in great depth, he concluded, "There are fairly strong suggestions in two papers by Freeman that the union/nonunion wage dispersion gap ... is considerably negative for male blue collar workers in manufacturing" (Union Relative Wage Effects, p. 200). "Fairly strong suggestions" from Gregg meant more to me than "proven clearly" or "shown conclusively" from your normal economist. Whew!

I relate these situations to give some flavor of how Lewis affected my thinking and that of many others. We felt his presence over our shoulders, and were better economists as a result. We paid attention to his judgment because we knew the odds were he would be right. To play such a Kuznetsian role requires a depth of understanding of what goes into empirical analyses, of the strengths and weaknesses of data, of how things fit together, and attention to the details of the research of others. Lewis was the conscience of labor economics because he had these virtues, and because he had an extraordinary devotion to getting things right. If Gregg had any ideological prior, it did not affect his reading of evidence: he was the social scientist par excellence in an area where people are often viewed as prounion or anti-union in their approach to questions.

The two union books have noticeable similarities, for they are the work of the same person, albeit separated by nearly 25 years, on essentially the same subject. The books are empirical-blatantly so. They never lose sight that the goal of social science is to measure purported effects of economic institutions or changes in markets nor of the limitations nonexperimental data place on meeting the goal. At times the books are tough reading. Lewis made sure that every step of every estimate was laid out in excruciating detail. And he interspersed the books with econometrics and theory of a personal old-fashioned kind that reflects the working of a master craftsman-a meister in applied economics. Faced with a problem of inference, Lewis did not reach for the latest computer package or consult with the newest vintage econometrician. Faced with a theoretical issue, Lewis did not call on the latest game theoretic treatment of asymmetric information. Shades of the Smith-Barney advertisement, he thought about the issues himself.

No discussion of Lewis's contribution could be complete without reference to his work on labor demand, embodied in his lecture notes. These notes are an extraordinary exhibit of clarity, organization, and exposition of technical material. Not the exposition of Galbraith or Stigler, to be sure. The notes are mostly equations, sans witticisms or jokes, but a marvel of exposition nonetheless. Assumptions are introduced and generalized in 
ways that bring economic issues to the fore. If the point of theory is to create a framework for thinking about economic problems, Lewis's demand lectures are an exemplar of good theory. If the point of teaching is to get students to think as economists, Lewis's demand lectures are an examplar of good teaching. Many demand theorems can be more readily proven through cost or profits functions than through the maximizing apparatus Lewis used. But Lewis's slow steady development of labor demand (he would spend a week on material that can be covered in a half-hour of mathematics) illuminated the economics far more than did alternative mathematical derivations.

Lewis's stress on the tools of factor demand analysis dominated his labor course when I took it. Indeed, labor supply decisions were treated as the demand for time in the household in the tradition of household production analysis. At the high point of human capital emphasis on supply, when labor economists were interpreting nearly everything from a supply perspective, Gregg reminded us that the market scissors has two blades. Hours of work. Investment in education. Wage determination. All affected by demand as well as supply. Human capital issues deserved in particular, he stressed, a more evenhanded treatment. The rise in income inequality in the 1980s has, of course, redressed this balance, though we need microestablishment panels to carry demand analyses as far as we have carried supply-oriented human capital analyses.

One of Lewis's great strengths was precision. In his lectures on labor demand he spent considerable time proving that inferior inputs had downward-sloping demand curves. Naively-I admit to never having heard of inferior inputs until Lewis's course-I raised my hand in class and asked why? Did he think inferior inputs were important or was there a key example behind this attention? Gregg was quiet for bit, then shook his head, he did not cover inferior inputs because they had great real-world content but because he wanted to give a complete analysis of demand. The lectures on factor demand were like a painting or piece of music, with every piece fitting together and nothing missing.

This desire for crossing t's and dotting i's is endemic of Gregg's work. You want to know how his partial equilibrium analysis of factor demand generalizes to a general equilibrium model with two sectors? You want to know whether introducing a capital market into Lewis's partial equilibrium approach would greatly affect the standard Marshallian conditions? You or I might respond by waving our hands and mumbling something about second-order effects and proceed. Lewis did not. He examined labor demand in two-sector models and gave a short numerical calculation that showed that under plausible values of factor shares, elasticities of substitution, and the like, the partial equilibrium analysis did quite well, thank you. Complete and precise. 
Precision and completeness were also, I think, Gregg's greatest weakness. He worked through the problems he analyzed with exemplary care and intelligence. Just as he built mobiles. Or as I envisage a pointillist painter doing his work. But the cost of precision and completeness is that one rarely takes giant jumps into the unknown. The "vision thing"-based as it must be on vague thoughts and insights-was not Gregg's strong suit. His goals were more modest or, as any honest social scientist knows, realistic: to measure the measurable and to clarify the meaning of what we did measure. In an area where speculators and visionaries abound, Lewis's determination to say what one could truly say from the evidence and no more teaches us something important. Those of us who interacted with Gregg Lewis think more clearly and precisely about labor problems because of him, and we carry his work and comments with us as a scientific conscience in our empirical analyses. We are lucky he didn't go into trade or finance or industrial organization or macroeconomics or some other silly field (though they need him desperately), but instead devoted himself to labor economics.

Richard B. Freeman Harvard University

\section{H. Gregg Lewis-Duke Days: 1975-1992_ the Mellow Years}

H. Gregg Lewis was a man of remarkable integrity, both in his professional life at Duke and in his personal life outside the department. In these pages, I will try to paint a picture of what it was like to know Gregg as a friend, as a colleague, and as a mentor during the years he spent at Duke and in Chapel Hill from 1975 to 1992.

Gregg and Julia (known to many as Judy) Lewis came to Duke in 1975. The story was that Professor T. Dudley Wallace called up Gregg, who was then visiting Princeton, to see if he was interested in visiting Duke. No, Gregg said, but he would entertain a job offer. After the shock wore off, an offer was produced posthaste. The offer was made in the Philadelphia Airport. As Gregg told it, it was one penny higher than his reservation wage.

So Julia and Gregg moved to the Triangle. Julia laughed because she had confused the geography of Durham with that of Charlottesville, only to find that Durham was not, after all, next to the mountains. The Lewises lived first at Wolf's Pond in the woods west of Chapel Hill, then on King Charles Road in Southwestern Durham, and finally in the wonderful dream house they designed and built in Chapel Hill.

In retrospect, the effort involved in those moves gives me pause. The household was large. Every box had to be packed, labeled, and taped just 
so. To this day I cannot close up a box without thinking of Gregg's method for taping it shut. Of course, moving household belongings was only a small part of the picture. The print collection had to be moved, the workshop set up, the gardening begun anew, the bird-feeding stations located, and warm hospitality extended to many guests.

The Lewises gardened seriously, both inside the house and out. Inside, precisely spaced, flourishing African violets covered the bank of windows on the east wall of the living room. Outside, the garden was integrated with the woods. They composted, and the barrel-shaped sieve that Gregg cranked to remove stones from the soil sat beside the driveway. Magical, stone-lined paths led to practical places-places like Julia's footstool positioned to reach the top of a bird feeder.

The Lewises frequently extended their warm hospitality to guestslocals and out-of-towners, economists and noneconomists, old and new friends. Dinner typically included red wine and loving stories of their Latin friends and of Chicago days. Large parties always included the graduate students. And of course there was no better treat than Gregg's homemade dill bread, pesto fresh from their garden, or Julia's famous chocolate mousse.

In those early days of the Lewises at Duke, colleagues at other institutions would inquire whether the Lewises had moved to Duke to retire. Retire? Who could keep pace with them? But there is a serious point. As they told it, they had long planned to move away from Chicago before they got too old to establish roots elsewhere. For them this meant both academic roots and community roots, and their plan was brilliantly executed.

As many of Gregg's friends know, Gregg was a man of considerable artistic talent and accomplishment. Among his works of art were beautifully balanced, multicolored mobiles, sensitive to the slightest air current. Long before Gregg came to Duke, a patron of the Art Institute of Chicago tried to commission Gregg to make a large version - more than one story highof one of his wooden mobiles to hang by the grand staircase in the entrance to the Art Institute in conjunction with a special exhibit of mobiles. Gregg refused on the grounds that the project would take an entire quarter away from his work.

Many of the Lewises' friends treasure a mobile from Gregg. He made these periodically and gave them away without fanfare. In my case, I returned to Durham from a sabbatical leave to find, to my delight, one hung in my living room. From time to time he turned out a batch of mobiles in his workshop. These were literally manufactured, in a systematic and organized way, with the considerable assistance of Julia. The workshop itself was a large cheery room, with big tables, power saws, and other equipment in the center, and with the perimeter walls of pegboard. The hand tools hung in groups on the pegboard-wrenches together, screwdrivers together, and so forth. Within each group, the tools were hung meticulously by size, 
the largest on the left, the smallest on the right. Gregg's only concession to the Second Law of Thermodynamics was the sawdust on the floor.

In the years Gregg was at Duke, his artistic output also included collages and latch hook rugs. Some of the rugs had big, bold patterns. Others represented the quintessential marriage of order with disorder. The sequence of colors of these beautifully striped rugs corresponded to "draws" from a table of random numbers.

Gregg and Julia delighted in their spectacular print collection. These prints occupied, or so it seemed, every inch of their considerable wall space. At the height of the collection it numbered two hundred seventysome. The story goes that long ago they decided they could afford either prints or framing but not both. So they made the frames themselves, simple, elegant, mahogany frames. Gregg had learned framing from a consultant to the Art Institute of Chicago, and they did museum quality work-acidfree paper, air-tight backings.

Of his politics I know very little, except for one thing. In presidential races, Gregg cast his ballot for a write-in candidate, Julia Catherine Lewis (Gregg's name for Julia in official matters). Gregg was a wonderful storyteller, and when he told of writing in Julia Catherine for president, he would chuckle, Julia would chuckle, his listeners would chuckle with them, and, as was often the case, warm tears of joy welled in Gregg's eyes.

The Lewises handled the many aspects of their lives-the moves, gardening, artistic endeavors, friend making and friend keeping, plus involvement with their three sons and eventually their grandchildren, and undoubtedly much more-all with apparent ease, organization, joy, and enthusiasm. This, then, was the backdrop for Gregg's work for the department, his research, his teaching, and his mentoring.

\section{Gregg Lewis and the Duke Economics Department}

H. Gregg Lewis had a pervasive influence on the Economics Department at Duke. He approached his service to the department as seriously as he did his scholarship.

By demanding so much of himself, he set high standards for all of us. One example must suffice. Gregg served on both departmental and university promotion and tenure committees. For each candidate he had a succinct, well-stated overview of the merits of the case. Moreover, his overview was grounded in intimate knowledge of the candidate's written work. If you wanted to disagree with Gregg's view, the onus was on you to take on Gregg's reasoning and evidence. He caused us to work as hard as he did.

He was also a mentor to several of us. To Gregg, any economist under the age of 40 was a "youngster." He always said the word "youngster" with warmth and care, for youngsters were to be helped and nourished. Once, while discussing over dinner the role of discussants and referees, 
Gregg laughed and said, "You need only point out that something is wrong. You need not call the author a stupid idiot."

But mostly he mentored in subtle ways and by example. You could take your theoretical and empirical work to Gregg and he would comment on your economics. He did this with a sophistication that belied his self-described lack of advanced techniques.

Or, as Orley Ashenfelter once described it, you could conduct a "Lewis Test," a test of importance in empirical labor economics. To conduct the Lewis Test, you took your empirical results to Gregg's office to see if Gregg thought they made sense. The Lewis Test had many advantages. It was quick, fun, and one always learned something. It was not a so-called portmanteau test of the sensibility of your results against some vague alternative. When your results failed the test, Gregg had a sharp economic reason.

His teaching was serious, a model of organization and the product of deep thought. At Duke, Gregg supervised six Ph.D. theses, spending untold hours with these students, some very talented, some not so talented. For several years, he taught the entire graduate labor sequence-a semester of supply and a semester of demand - with much emphasis on human capital and the new home economics. In its first year, there were only two graduate students, and in retrospect I realize they must have had a rough timethere were no less than seven faculty, from the University of North Carolina, from North Carolina State University, and from Duke, sitting in on Gregg's lectures! We struggled to distinguish his partials from his totals. In small, neat script, he wrote "EY/EZ." But his course was too rich to be easy.

Of course, he was equally devoted to undergraduate teaching. He regularly taught an undergraduate labor course as well as Principles of Microeconomics back when Principles was offered in small sections. One of his early labor students was Jim Baumgardner, who is now our colleague at Duke.

Many of Gregg's students revered him, and not just his good students. One day at the end of the semester, I walked into the Economics Department office to find Katie Frye, one of our secretaries, quite upset. Katie was fond of Gregg. It seemed that Professor Lewis had found a cake left for him outside his office door and had taken it home to eat. But, Professor Lewis had just flunked the young woman who had baked that cake. Moreover, the baker knew Professor Lewis had flunked her-no asymmetric information here. The fact that Gregg had tutored this student throughout the semester did not dissuade Katie from the notion that the cake was surely poisoned. Of course, as Julia can testify, the cake was delicious.

Once he taught one of those short (long weekend) courses to Duke alums, titled something like "Labor for the Noneconomist." He opened 
his first lecture by explaining how, ceteris paribus, those who were taking this course had a low opportunity cost of time.

He had a favorite example on price regulation, drawn from his Chilean days. It went something like this. The Chilean government fixed the price of a 1-kilo loaf of bread. What, Gregg would ask, do you think was the impact of this regulation? He delighted in revealing the impact: The bakers underbaked the 1-kilo loaves, leaving them overly moist. When consumers finished baking their loaves at home, they no longer weighed a full kilo.

While at Duke, Gregg's scholarly work continued. Gregg worked on a paper on general versus partial equilibrium, which became something of an underground classic of small circulation. His scholarly accomplishments included the writing of his second book, Union Relative Wage Effects: A Survey (Chicago: University of Chicago) which was published in 1986, two years after his retirement. In 1976, the Journal of Political Economy had a special issue in his honor, and many distinguished economists traveled to Durham to celebrate the event. In 1980, Gregg was elected a vice-president of the American Economic Association, and in 1981 he was made a Distinguished Fellow of the American Economic Association. The Journal of Labor Economics made his article the lead article in its inaugural issue (January 1983). In May of 1983, he won the Duke University ScholarTeacher Award (sponsored by the United Methodist Church), and in 1986 he was made a fellow of the American Academy of Arts and Sciences. Since 1984, the Economics Department has annually awarded the prestigious H. Gregg Lewis Fellowship to an incoming graduate student.

\section{Retirement}

Gregg officially retired in 1984 . But in practice, his retirement was gradual. In addition to finishing "the book," he continued to teach undergraduate labor economics for years and was active in the department, attending workshops and faculty meetings. Gradually, as his health encumbered him, his attendance slacked off.

Despite health problems, this was not a sad time. Gregg's "retirement" was a time filled with art projects, trips to the beach, friends, and family.

But, in 1990, at an NSF panel meeting, someone remarked that Gregg must have "really retired." His evidence consisted of a referee's report that Gregg had authored. While still more carefully done than the reports of many others, this report of Gregg's was only one paragraph long.

\section{A Few Summary Comments}

For many of us the lessons of Gregg's life are far too broad to be thought of as merely professional. There was a unity in the integrity so manifest in both his professional and personal life. He was a superbly economic man who led an incredibly rich and diverse life-well planned and frugally 
executed. He was the model of tight, logical reasoning, but his reasoning was at the service not only of economics, but also of art and music, of his family, and of the joy of living itself. He set high standards for himself and, by example, for those around him. He was brutally honest, yet warm and generous. If he spoke of his travails, it was with humor, grace, and infectious amusement. In both health and sickness, he was always organized, positive, and working on life.

In May of 1992, our graduate students held a Labor Lunch Workshop in his honor. Three students summarized Gregg Lewis's accomplishments as a scholar and a teacher. Dudley Wallace contributed a personal sketch of Gregg, as this was the first cohort of students deprived of Gregg's influence. Julia was there. As this workshop was basically a student project, it constituted an uncannily fitting tribute to this great teacher.

H. Gregg Lewis died on January 25, 1992, at the age of 77 . We at Duke were privileged to have known him as a colleague and friend. We revere his memory and miss him sorely.

Marjorie B. McElroy Duke University 